\title{
Environmental Hydro chemistry and genesis of fluoride in drinking water of Govt kallar Hr. Sec Schools, in Dindigul District in Tamilnadu India.
}

\author{
M. Amutha ${ }^{1,}$ A.Gubendran ${ }^{2}$, B.Jeyaprabha ${ }^{3}$ and P.Prakash ${ }^{4} *$ \\ ${ }^{1}$ (Assistant professor Department of Chemistry, VVVannia Perumal College for Women Virudhunagar, \\ Tamilnadu, INDIA-) \\ ${ }^{2}$ (Assistant professor Department of Chemistry, Saraswathi Narayanan College perungudi-Madurai, \\ Tamilnadu ,INDIA) \\ ${ }^{3}$ (Assistant professor Department of Civil Engineering, Fatima Michael College of Engg. \& Tech., Madurai, \\ Tamilnadu, INDIA \\ ${ }^{4}$ (Assistant professor Department of Chemistry, Thiagarajar College, Madurai, 625 009, Tamilnadu INDIA)
}

\begin{abstract}
Our life is governed by the seasons rhythms. Mainlyhydrology and rainfall depend on the monsoons and make a reasonable impact in the day-to-day life.In thepresent study an attempt has been made to identify the drinking water quality of Govt kallar Hr. Sec Schoolsin Dindigul district during Premonsoon and Post monsoon phases in the year of 2010-2012. The physico-chemical parameters like pH,Electrical conductivity, Total hardness, Total alkalinity, Chloride, Sulphate, Sodium, Fluoride, Potassium, Calcium Magnesium, Nitrate and Heavymetals were studied to analyze the potable ground water quality of the four schools. Meaningful conclusion has been drawn by applying Multistatistical approach such as Box and Whiskers plot, cluster analysis and principal component analysis [1-5]. Chemical relationships in the water quality parameters are explained by cluster analysis. Better water quality was found in Pre-monsoon season than Post-monsoon season. Multivariate statistical analysis explained thatfour Govt. Kallar. Hr. Sec. Schools in Dindigul district are not having potable water. Extent of pollutionoccurred due to dissolution of minerals into rain water with raise in water tableof the drinking water sources. Water sources are affected on account of overexploitation of ground water, urbanization and anthropogenic activities.
\end{abstract}

Key words: Ground Water, Water Quality, Box and Whiskers plot, Cluster analysis, principal component analysis over exploitation, Anthropogenic activities.

\section{Introduction}

Ground Water is a renewable natural resource, which is replenished annually by the precipitation. Ground Water quality plays an important role in groundwater protection and quality conservation. Hence, it is very important to assess the groundwater quality not only for its present use but also from the viewpoint of a potential source of water for future consumption. It is well known that occurrence of ground water and its availability for various uses is controlled by the nature of rock formation in which it occurs as well as geological structures, geomorphologic and hydrological setting and hydro metrological conditions [6-8].

Previous research on groundwater quality and drinking water supply between 1990 and 2012 has been carried out in Dindigul district and found the fluoro genesis area and the innovative techniques were implemented to reduce the contamination].However ground water as an essential resource in Dindigul district shall regularly be monitored to ensure its protection from contamination.

The present study focused on assessment of hydro chemical quality of ground water samples collected from Bore wells located in four Govt. Kallar. Hr.Sec. Schools in Dindigul district to compare the results with the different standards and to illustrate ground water suitability for utilizations in drinking, through the calculation of cluster, principal component analysis and Box and whiskers plot. During the sampling periods, severe drinking water shortage and weak drinking water storage practices have also been observed. In some areas, very old cement over tankers which may stay for over six months without cleaning were used to store drinking water and in other areas mainly in tankers made from plastic and clay without covers and necessary cleanups were used to store drinking water. All this together enhance the risk on human health.

Fluoride contaminated schools and the other major ions related with fluoride to degrade the quality of water during post and premonsoon seasons have been identified and the innovative defluoridation techniques will be implemented to provide the pure drinking water to the poor school children. Name of theanalyzed schools are given in the table-1 
Table-1Name of the schools located in Dindigul District and their codes

\begin{tabular}{|l|l|}
\hline School Code & \\
\hline S1 & Government Kallar Hr.Sec School at Kondamanaickenpatti \\
\hline S2 & Government Kallar Hr.Sec School at Vilampattti \\
\hline S3 & Government Kallar Hr.Sec School at AnaiPatti \\
\hline S4 & Government Kallar Hr.Sec School at KamupillaiChattram \\
\hline
\end{tabular}

\section{Results And Discussion}

The mean values of various parameters determined in the drinking water samples are summarized in the table 1 and subjected to statistical approach to draw meaningful conclusions. EC, TDS, TA, TH, F, $\mathrm{HCO}_{3}$, $\mathrm{SO}_{4}$, Chloride, $\mathrm{Ca}, \mathrm{Mg}$ and $\mathrm{Na}$ were higher than the permissible limit.So the water is not for potable and hence further treatment is needed before usage. The $\mathrm{pH}$ mean value shows the alkaline nature of water during pre and post monsoon seasons with slight seasonal variations. It infers the alkaline nature of water and the favourable chance for fluoro genesis. High concentration of major ions infers the hardness and the salinity of drinking water. Heavy metals are toxic because they may have cumulative deleterious effects that can cause chronic degenerative changes, especially to the nervous system, liver, and kidneys, and, in some cases, they also have teratogenic and carcinogenic effects. The mechanism of toxicity of some heavy metals still remains unknown, although enzymatic inhibition, impaired antioxidants metabolism, and oxidative stress may play a role. Heavy metals generate many of their adverse health effects through the formation of free radicals, resulting in DNA damage, lipid peroxidation, and depletion of protein sulfhydryl[9-14].

Table-2-Analysed parameters for samples in Dindigul district

\begin{tabular}{|l|l|l|l|l|l|l|}
\hline \multirow{2}{*}{ WQPs } & \multicolumn{3}{|l|}{ Post-Monsoon 2010-11 } & \multicolumn{2}{l|}{ Pre-Monsoon 2010-11 } \\
\cline { 2 - 7 } pH & Min. & Max. & Avg. & Min. & Max. & Avg. \\
\hline EC & 7.70 & 8.10 & 7.90 & 7.40 & 7.70 & 7.60 \\
\hline TDS & 790 & 6320 & 2817.5 & 320 & 4090 & 1752.5 \\
\hline TA & 431 & 3502 & 1532.25 & 170 & 2285 & 960.25 \\
\hline TH & 310 & 550 & 431.25 & 115 & 575 & 362.5 \\
\hline $\mathbf{C l}^{-}$ & 350 & 2220 & 850 & 140 & 1120 & 538.75 \\
\hline $\mathbf{S O}_{4}{ }^{2-}$ & 32 & 1489 & 437 & 28 & 830 & 292.5 \\
\hline $\mathbf{F}^{-}$ & 17 & 576 & 162.25 & 17 & 288 & 91.5 \\
\hline $\mathbf{H C O}_{3}{ }^{2-}$ & 0.4 & 1.9 & 1.115 & 0.5 & 1.9 & 0.9375 \\
\hline $\mathbf{N O}_{3}$ & 378 & 671 & 526 & 240 & 702 & 483 \\
\hline $\mathbf{C a}^{2+}$ & 2 & 45 & 17.75 & 8 & 74 & 29.5 \\
\hline $\mathbf{M g}^{2+}$ & 40 & 344 & 132 & 32 & 200 & 92.5 \\
\hline $\mathbf{N a}^{+}$ & 51 & 331 & 126.5 & 15 & 151 & 75 \\
\hline $\mathbf{K}^{+}$ & 20 & 442 & 152.5 & 11 & 442 & 162 \\
\hline $\mathbf{D O}^{\mathbf{C}}$ & 3 & 11 & 7.75 & 2 & 5 & 3.25 \\
\hline $\mathbf{C O D}^{\mathbf{B O D}}$ & 6.8 & 7.4 & 7.05 & 5.6 & 7 & 6.25 \\
\hline
\end{tabular}

*All the values are $\mathrm{mg} \mathrm{L}^{-}$except $\mathrm{pH}$ and $\mathrm{EC}$

Table 3.Distribution of Heavy Metals during 2010-2011 Post Monsoon

\begin{tabular}{|l|r|r|r|r|r|}
\hline Seasons & \multicolumn{1}{|l|}{ Copper } & \multicolumn{1}{l|}{ Zinc } & \multicolumn{1}{l|}{ Iron } & \multicolumn{1}{l|}{ Nickel } & Chromium \\
\hline 2010/11 POST & 1.416 & 0 & 10.21 & 0.321 & 0.222 \\
\hline 2010/11 POST & 1.430 & 0 & 10.45 & 0.312 & 0.267 \\
\hline 2010/11 POST & 1.261 & 0 & 8.532 & 0.297 & 0.211 \\
\hline 2010/11 POST & 1.259 & 0 & 10.851 & 0.367 & 0.231 \\
\hline
\end{tabular}

Table 4Distribution of Heavy Metals during 2010-2011 pre Monsoon

\begin{tabular}{|l|r|r|r|r|r|}
\hline Seasons & \multicolumn{1}{|c|}{ Copper } & \multicolumn{1}{c|}{ Zinc } & \multicolumn{1}{c|}{ Iron } & Nickel & Chromium \\
\hline 2010/11 PRE & 1.321 & 0 & 10.11 & 0.471 & 0.338 \\
\hline 2010/11 PRE & 1.31 & 0 & 10.52 & 0.411 & 0.341 \\
\hline 2010/11 PRE & 1.212 & 0 & 8.435 & 0.478 & 0.362 \\
\hline 2010/11 PRE & 1.21 & 0 & 10.251 & 0.432 & 0.335 \\
\hline
\end{tabular}

\section{Box and whisker plots}

Box and whisker plots show the spatial and seasonal variations in the concentrations of fluoride. As shown in fig-1, the five statistical summaries such as the size and position of the box, upper and lower whiskers, mean and outliers of the Box plots are different for both the seasons. Thus it understood that the seasonal and spatial variations have been observed in the content of fluoride [15-20]. 


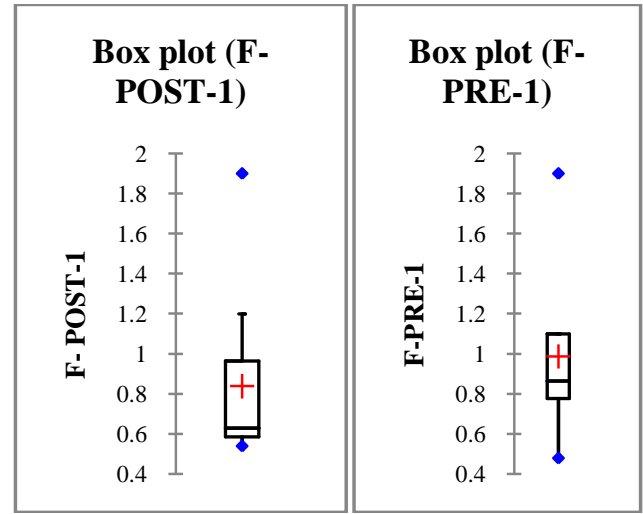

Figs-1 and2Box and whisker plots for Total alkalinity of 8 schools in Dindigul District during post and premonsoon seasons of year 2010-2011.

\section{Cluster analysis:}

During post monsoon season the dendrogram for water quality parameters show four clusters. As shown in table-2 Cluster -1 comprises TH,TA, $\mathrm{HCO}_{3}{ }^{-}$, and hardness, cluster -2 compriseslarge number of parameters and play a key role to determine the character of water.Cluster-3 comprisesEC,and cluster-4 comprises TDS.The pollution of water quality is in the decreasing order as clusters1 $>2>3>4$.

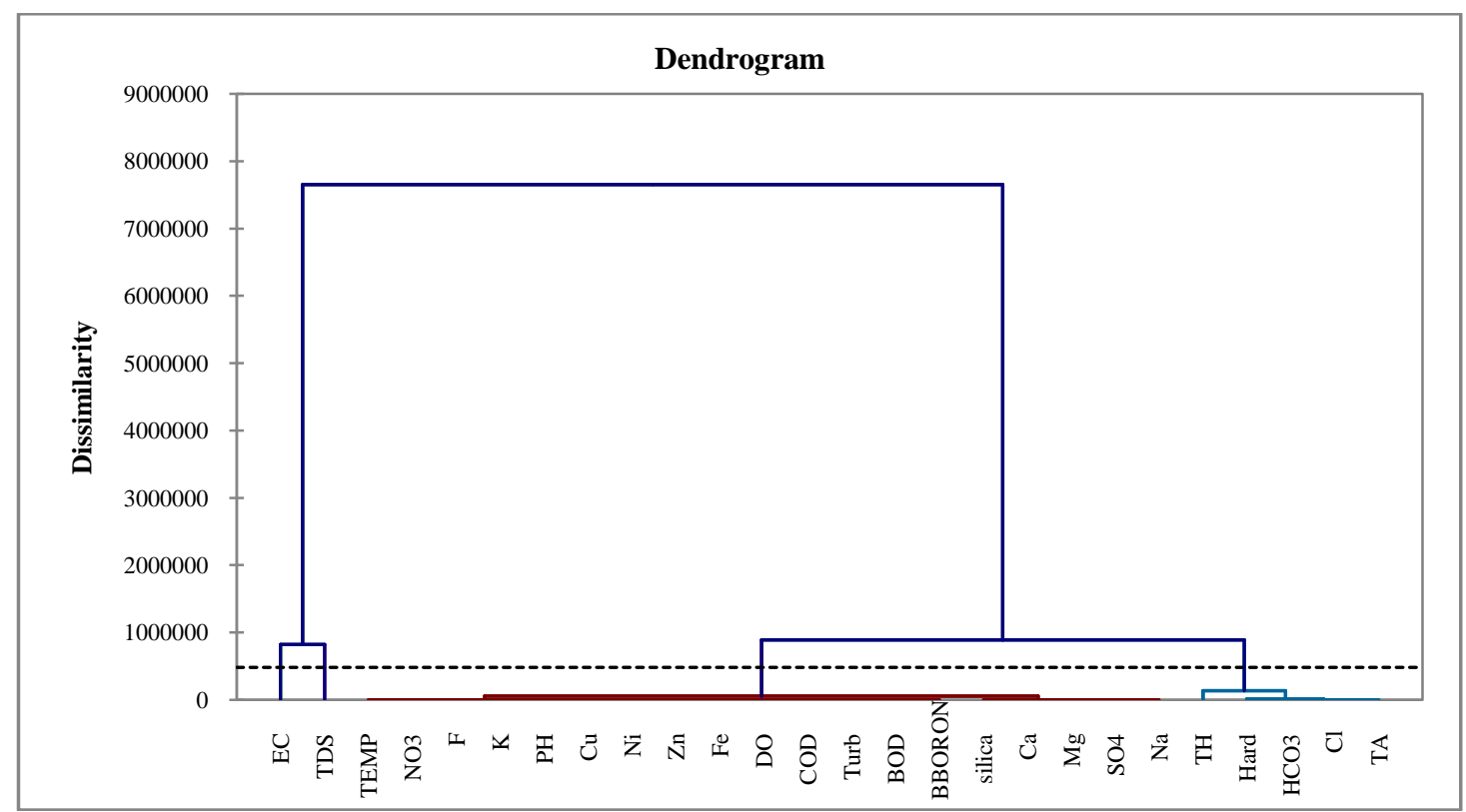

Fig-3Dendrogram of water quality parameters of Dindiguldistrict during post monsoon season of year 2010-2011

Table-4total clusters with water quality parameters during post monsoon season of year 2010-2011

\begin{tabular}{|c|c|c|c|}
\hline cluster-1 & cluster-2 & cluster-3 & cluster-4 \\
\hline TH & $\mathrm{Ca}$ & EC & TDS \\
\hline $\mathrm{Cl}$ & $\mathrm{Mg} 2+$ & & \\
\hline TA & SO4 2- & & \\
\hline $\mathrm{HCO} 3$ & $\mathrm{Na}+$ & & \\
\hline \multirow[t]{3}{*}{ Hard } & $\mathrm{K}+$ & & \\
\hline & F- & & \\
\hline & $\mathrm{PH}$ & & \\
\hline \multicolumn{3}{|c|}{ Temperature } & \\
\hline & NO3 & & \\
\hline & Turbidity & & \\
\hline & DO & & \\
\hline & COD & & \\
\hline & BOD & & \\
\hline & Borane & & \\
\hline & Silicate & & \\
\hline & COPPER & & \\
\hline & CHROMIUI & & \\
\hline & IRON & & \\
\hline & NIKEL & & \\
\hline
\end{tabular}


It was found that $\mathrm{Mg}^{2+}, \mathrm{Ca}^{2+} \mathrm{Na}^{+} \mathrm{K}^{+}$and $\mathrm{F}^{-}, \mathrm{Cl}^{-}, \mathrm{HCO}_{3}{ }^{-}$are the dominant cations and anions and heavy metals are also affected drinking water sources in the area. The clusters defined by Q-mode analysis reflect the spatial distribution of samples and the R-mode cluster conveys that salinity, heavy metals and major ions form one group. The same trend has been observed in pre- monsoon season with slight variation of the concentrations of the parameters. It proves the geogenic nature of fluoride on account of the minerals such as $\mathrm{CaF}_{2}, \mathrm{KF}_{\text {in }}$ the rock types and other anthropogenic factors[21-28].

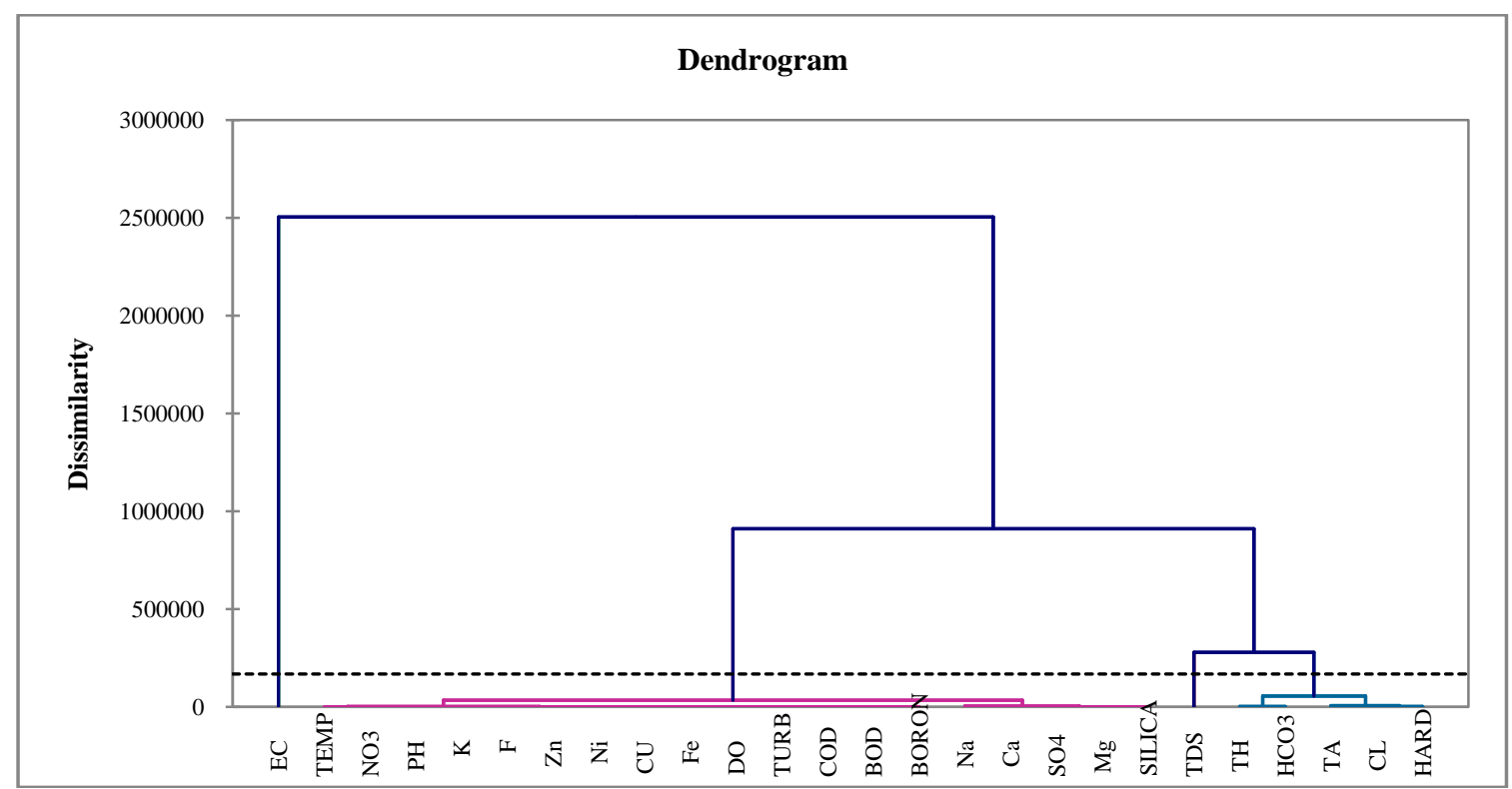

Fig-4Dendrogram of water quality parameters for Dindigul District during pre monsoon season of year 2010-2011

Table-5 total clusters with water quality parameters during pre monsoon season of year 2010-2011

\begin{tabular}{|l|l|l|l|}
\hline cluster-1 & cluster-2 & cluster-3 & cluster-4 \\
\hline TH & Ca2+ & EC & TDS \\
\hline Cl- & Mg2+ & & \\
\hline TA & SO42- & & \\
\hline HCO32- & Na+ & & \\
\hline Hardness( + K+ & & \\
\hline F- & & \\
\hline PH & & \\
\hline Temperature & \\
\hline NO3 & \\
\hline Turbidity & \\
\hline DO & & \\
\hline COD & \\
\hline BOD & \\
\hline Borane & \\
\hline Silicate & \\
\hline COPPER & \\
\hline CHROMIUM & \\
\hline IRON & \\
\hline NIKEL & \\
\hline
\end{tabular}

\section{Principal componant analysis}

As shown in table 6 to 9 the principal component/ Factor analysis explained the dominant parameters comprised in factor-1 and moderately loaded parameters are in factor- 2 . For the post monsoon season , factor1 explains $60.1 \%$ of total variance of the following water quality parameters in descending order as DO $>$ COD $>\mathrm{BOD}>\mathrm{Tub}>$ boron $>\mathrm{TA} \quad \mathrm{HCO}_{3}{ }^{-}>\mathrm{TH}>\mathrm{NO}_{3}{ }^{-}>\mathrm{Cu}>\mathrm{Zn}>\mathrm{Fe}>\mathrm{TA}>\mathrm{Cl}>\mathrm{EC}$. Factor -2 explains $39.5 \%$ of the total variance of the following the water quality parameters in descending order as $\mathrm{F}^{-}>\mathrm{pH}^{>}$ $\mathrm{K}^{+}>\mathrm{Temp}>\mathrm{Mg}^{2+}>\mathrm{Ca}^{2+}>\mathrm{Na}^{+}>\mathrm{SO}_{4}{ }^{2-}>$ Hard $>$ TDS.

For the pre monsoon season factor -1 explains $59.4 \%$ of total variance of the following the water quality parameters in descending order as $\mathrm{DO}>\mathrm{COD}>\mathrm{BOD}>\mathrm{NO} 3>\mathrm{HCO}>\mathrm{TH}>\mathrm{Turb}>$ boron $>\mathrm{TA}>\mathrm{Cu}>\mathrm{Zn}>\mathrm{Fe}$ $>\mathrm{Cl}>\mathrm{EC}>$.Factor -2 explains $40.1 \%$ of the total variance of the following the water quality parameters in descending order as $\mathrm{F}>\mathrm{PH}>\mathrm{K}>\mathrm{Temp}>\mathrm{SO} 4>\mathrm{Ca}>\mathrm{Mg}>\mathrm{Na}>\mathrm{TDS}$. Total hardness, alkalinity, 
heavy metals and biological properties highly affect the water quality in post monsoon on account of dissolution of minerals, and other impurities dissolved in rain water with raise in water table[29-33].

\section{Rotated factor analysis}

Scattered plot (Fig 5) shows the clusters of parameters in 4 coordinates. It infers that the EC, and TDS are highly affected the water quality. Biological properties and major ions affect the water quality at the same rate. The impact of heavy metals are high in Dindigul confirms the impact of industrial pollutions.

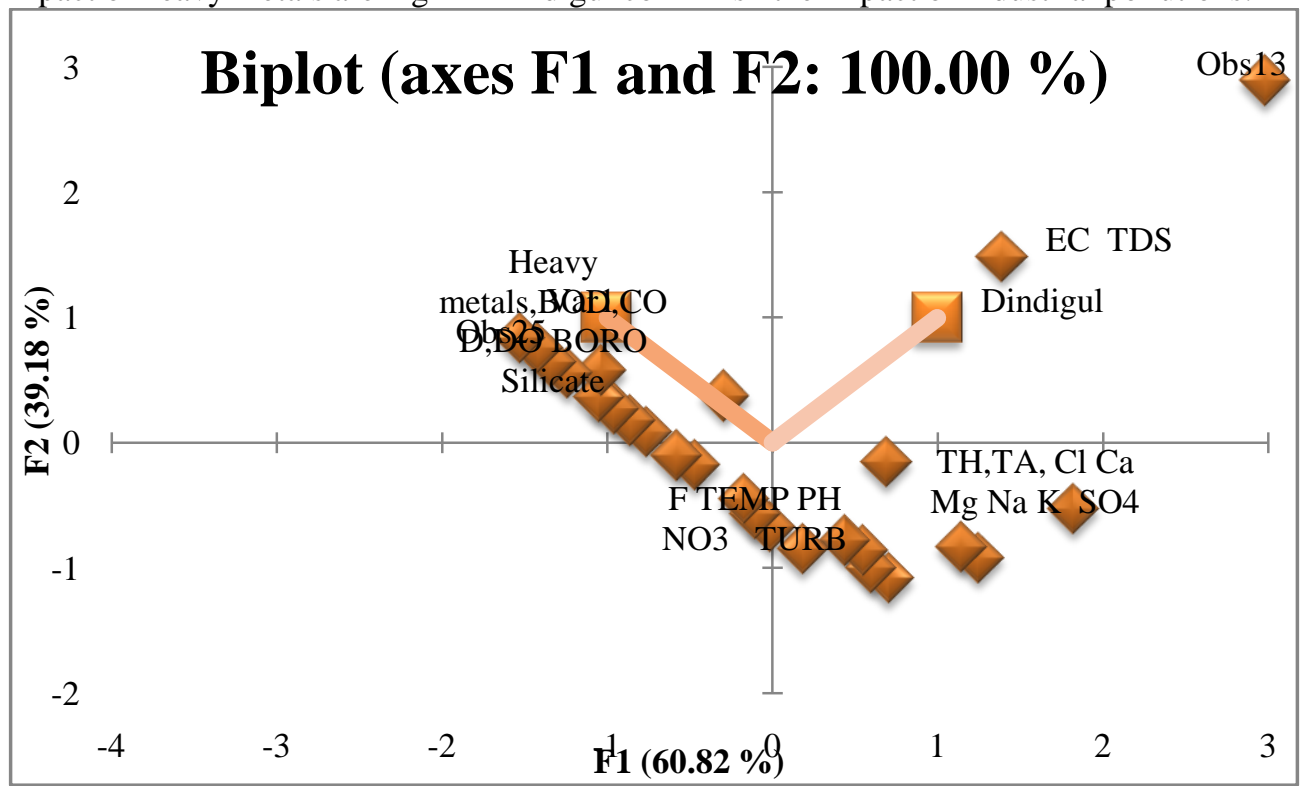

Fig-5 Rotated factor analysis for water quality parameters.

\section{Box and whisker plots for evaluate the spatial and seasonal variations (figures not shown)}

It explains the different statistical summary for the 4 schools of all the parameters for all the season during analyzed period. This difference infers the seasonal and spatial variations in water quality.

\section{Cluster analysis}

Cluster analysis explains that all the 4 schools are present in different geographical locations, which infers that 4 clusters for 4 schools.

Post monsoon shows strong impact than pre monsoon on account of mineral dissolution into rainwater, Coir industries; leather industries are nearer to the school locations [34]. 
Environmental Hydro chemistry and genesis of fluoride in drinking water of GovtkallarHr...

Table-6and7 factor scores and \% of contribution of water quality Squared cosines of the observations:

\begin{tabular}{|c|c|c|c|c|c|}
\hline & & & \multicolumn{3}{|c|}{ Contribution of the observations (\%): } \\
\hline & F1 & F2 & & & \\
\hline $\mathrm{TH}$ & 0.921 & 0.079 & & $\mathrm{~F} 1$ & $\mathrm{~F} 2$ \\
\hline $\mathrm{Cl}-$ & 0.649 & 0.351 & $\mathrm{TH}$ & 10.520 & 1.394 \\
\hline TA & 0.656 & 0.344 & $\mathrm{Cl}-$ & 4.933 & 4.149 \\
\hline $\mathrm{Ca} 2+$ & 0.297 & 0.703 & TA & 4.168 & 3.396 \\
\hline $\mathrm{Mg} 2+$ & 0.269 & 0.731 & $\mathrm{Ca} 2+$ & 1.574 & 5.787 \\
\hline $\begin{array}{l}\mathrm{SO} 42- \\
\mathrm{Na}+\end{array}$ & 0.291 & $\begin{array}{l}0.709 \\
0.753\end{array}$ & Mg2+ & 1.156 & 4.889 \\
\hline $\mathrm{K}+$ & 0.044 & 0.956 & SO4 2- & 0.964 & 3.648 \\
\hline $\mathrm{HCO} 32-$ & 0.952 & 0.048 & $\mathrm{Na}+$ & 0.630 & 2.980 \\
\hline F- & 0.000 & 1.000 & $\mathrm{~K}+$ & 0.107 & 3.574 \\
\hline $\mathrm{PH}$ & 0.029 & 0.971 & HCO32- & 1.517 & 0.119 \\
\hline Temperat & 0.123 & 0.877 & F- & 0.001 & 2.220 \\
\hline EC & 0.516 & 0.484 & $\mathrm{PH}$ & 0.031 & 1.597 \\
\hline TDS & 0.467 & 0.533 & Temperat & 0.091 & 1.006 \\
\hline $\mathrm{NO} 3$ & 0.867 & 0.133 & EC & 28.131 & 40.947 \\
\hline $\begin{array}{l}\text { Turbidity } \\
\text { Hardness( }\end{array}$ & 0.966 & $\begin{array}{l}0.034 \\
0.620\end{array}$ & TDS & 6.131 & 10.849 \\
\hline DO & 0.987 & 0.013 & NO3 & 0.683 & 0.162 \\
\hline COD & 0.958 & 0.042 & Turbidity & 1.061 & 0.057 \\
\hline BOD & 0.926 & 0.074 & Hardness( & 0.265 & 0.673 \\
\hline Borane & 0.893 & 0.107 & DO & 1.826 & 0.039 \\
\hline Silicate & 0.766 & 0.234 & COD & 2.328 & 0.157 \\
\hline COPPER & 0.833 & 0.167 & BOD & 2.887 & 0.358 \\
\hline CHROMIU & 0.810 & 0.190 & Borane & 3.492 & 0.648 \\
\hline IRON & 0.780 & 0.220 & Silicate & 3.368 & 1.599 \\
\hline NIKEL & 0.769 & $\frac{0.231}{E 2}$ & COPPER & 4.846 & 1.503 \\
\hline Eigenvalu & 1.216 & 0.784 & CHROMIU & 5.623 & 2.051 \\
\hline Variability & 60.818 & 39.182 & IRON & 6.344 & 2.776 \\
\hline Cumulativ & 60.818 & 100.000 & NIKEL & 7.325 & 3.422 \\
\hline
\end{tabular}


Table-8and 9 factor scores and \% of contribution of water quality parameters for pre monsoon Squared cosines of the observations:

\begin{tabular}{|c|c|c|c|c|c|}
\hline & F1 & F2 & & & \\
\hline TH & 0.914 & 0.086 & & F1 & $\mathrm{F} 2$ \\
\hline $\mathrm{Cl}-$ & 0.653 & 0.347 & $\mathrm{TH}$ & 10.075 & 1.552 \\
\hline TA & 0.777 & 0.223 & $\mathrm{Cl}-$ & 4.870 & 4.244 \\
\hline $\mathrm{Ca}+$ & 0.287 & 0.713 & TA & 5.147 & 2.420 \\
\hline Mg2+ & 0.232 & 0.768 & $\mathrm{Ca} 2+$ & 1.498 & 6.095 \\
\hline SO4 2- & 0.236 & 0.764 & $\mathrm{Mg} 2+$ & 1.002 & 5.426 \\
\hline $\begin{array}{l}\mathrm{Na}+ \\
\mathrm{K}+\end{array}$ & $\begin{array}{l}0.385 \\
0.029\end{array}$ & $\begin{array}{l}0.615 \\
0.971\end{array}$ & SO4 2- & 0.790 & 4.195 \\
\hline $\mathrm{HCO} 32-$ & $\begin{array}{l}0.029 \\
0.989\end{array}$ & 0.011 & $\mathrm{Na}+$ & 0.907 & 2.377 \\
\hline F- & 0.003 & 0.997 & $\mathrm{~K}+$ & 0.073 & 3.965 \\
\hline $\mathrm{PH}$ & 0.040 & 0.960 & HCO32- & 2.774 & 0.049 \\
\hline Temperat & 0.130 & 0.870 & F- & 0.005 & 2.484 \\
\hline EC & 0.516 & 0.484 & $\mathrm{PH}$ & 0.046 & 1.785 \\
\hline TDS & 0.466 & 0.534 & Temperat & 0.098 & 1.078 \\
\hline $\mathrm{NO}_{3}$ & $\begin{array}{l}0.872 \\
0.953\end{array}$ & 0.128 & EC & 26.363 & 40.481 \\
\hline $\begin{array}{l}\text { Turbidity } \\
\text { Hardness( }\end{array}$ & \begin{tabular}{|l|}
0.953 \\
0.333
\end{tabular} & $\begin{array}{l}0.047 \\
0.667\end{array}$ & TDS & 5.711 & 10.709 \\
\hline DO & 0.993 & 0.007 & NO3 & 0.650 & 0.156 \\
\hline COD & 0.971 & 0.029 & Turbidity & 1.139 & 0.093 \\
\hline BOD & 0.942 & 0.058 & Hardness( & 0.231 & 0.759 \\
\hline Borane & 0.911 & 0.089 & DO & 1.902 & 0.021 \\
\hline Silicate & 0.753 & 0.247 & COD & 2.420 & 0.119 \\
\hline COPPER & 0.852 & 0.148 & BOD & 2.985 & 0.302 \\
\hline $\begin{array}{l}\text { CHROMIU } \\
\text { IRON }\end{array}$ & $\begin{array}{l}0.828 \\
0.794\end{array}$ & $\begin{array}{l}0.172 \\
0.206\end{array}$ & Borane & 3.596 & 0.575 \\
\hline \multirow[t]{2}{*}{ NIKEL } & 0.786 & 0.214 & Silicate & 3.215 & 1.730 \\
\hline & $\mathrm{F} 1$ & $\mathrm{~F} 2$ & COPPER & 4.950 & 1.409 \\
\hline Eigenvalu & 1.242 & 0.758 & CHROMIU & 5.730 & 1.948 \\
\hline Variability & 62.118 & 37.882 & IRON & 6.395 & 2.714 \\
\hline Cumulativ & 62.118 & 100.000 & NIKEL & 7.427 & 3.315 \\
\hline
\end{tabular}

\section{Concentration of heavy metals}

Concentrations of heavy metals during post monsoon are higher than the pre monsoon season.As shown in fig-6 Iron is higher than the other metals on account of improper plumbing work of water supplying systems. But all the other metal concentrations are within the permissible limit.

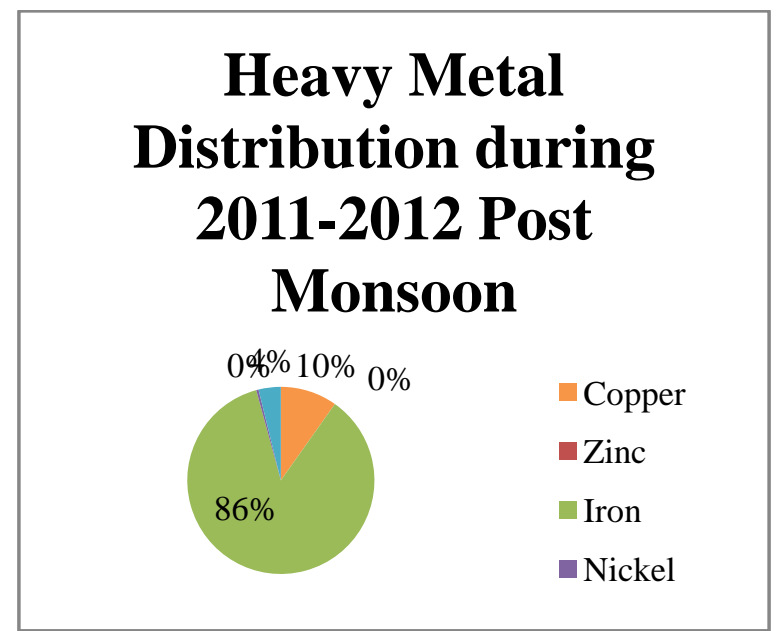

Fig-6 Distribution of Heavy Metals of Theni District schools during 2010-2011 Post Monsoon

\section{Conclusion}

For the last two consecutive years Tamilnadu is facing a worst ever water crisis that has implications not only for high population density but for the seasonal variations. In Dindigul district four Govt. KallarHr Sec Schools are facing poor water quality problems. During Post monsoon season students and the public are suffering from water related diseases onaccount of the high dissolution of minerals like Fluoride, Calcium, Magnesium, and heavymetals. Dental and skeletal 1 fluorosis affects the people by taking the contaminated water.The hydro geo chemical relationship of the samples was obtained from Multivariate statistical analysis. 
There is a strong positive interrelation among TA,TH,TDS, EC and Major ions.Majority of the water samples are under medium -high salinity hazard.

Scientists have the power to avoid this bleak future of the school children and the people who are taking water. We have planned to takemeasures immediately to implement the novel defluoridation technique in safe manner. This study, therefore, recommends the government and other authorities concerned tosupport further study to be conducted on other physical, chemical and biological parameters of significant health concern and on identification of potential sources of the contaminants including heavy metal contaminants.

\section{References}

[1]. R.N.Subba. Seasonal variation of ground water quality in a part of Guntur district, Andhra Pradesh, India. Environ. Geol. 49 2006 413-429.

[2]. M.R..Sudhakar,P. Mamatha Water quality in sustainable water management. Curr. Sci. 87(7)2004.942-947.

[3]. WHO (1993) Guidelines for drinking water. Vol. 2, Recommendations, World Health Organization Geneva

[4]. APHA (1995) Standard methods for the examination of water and wastewater, 17thedn. APHA, Washington, DC

[5]. W.M.Edmunds, P.Shand, P.Hart,R.S. Ward The natural (baseline) quality of groundwater: a UK pilot study. Sci Total Environ 310 200325-35.

[6]. P.C.Mishra,P.C.Behera,R.K. Patel Contamination of water due to major industries and open refuse dumping in the steel city of Orissa-a case study. J Environ SciEng 47(2) 2005 141-154

[7]. R.N.Tiwari Geochemical studies of Groundwater in SemariyaTeheil, Rewa District Madhya Pradesh, India. Proc. Int. Groundwater Conf. Madurai, India 2011, pp. 679-678.

[8]. BIS (1991). Bureau of Indian Standard Specification for Drinking Water ISI : 10500.

[9]. L.Chiman,J.SJiu. Heavy metal and trace element distribution in groundwater in natural stops and highly urbanised spaces in Mid level area Howngkong. Water Res. 40(4) 2006 753-76.

[10]. Z.Demirel. Monitoring of heavy metal pollution of groundwater in a phreatic aquifer in Mersin-Turkey. Environ. Monit. Assess. 132(1-3) 2007 15-23

[11]. R.C.Dixit ,S.R. Verma,V. NitnaWare,N.P. Thackere Heavy metal contamination in surface and groundwater supply of an urban city. Indian J. Environ. Health 45(2) 2003. 107-112.

[12]. Khan MQMA,R. Umar, H.Latch. Study of trace elements in groundwater of Uttar Pradesh, India. Sci. Res. Essays 5(20)2010 31753182 .

[13]. A.K.Krishna,P.K. Govil Heavy metal contamination of soil around Pal. industrial area, Rajasthan, India. Environ. Geol. 47 2004 38-44.

[14]. S. Khurshid., Zaheeruddin and M.U. Shabeer,. Degradation of Water Quality due to Heavy Metal Pollution in Faridabad District, Haryana, India. Poll. Res., 16(1), 200741-43

[15]. BIS, Indian Standards for drinking water - specification (IS10500:1991), Bureau of Indian Standards, New Delhi, 1991.

[16]. N. SubbaRao, and D.J Devdas, , Fluoride incidence in groundwater in an area of peninsula India. Environ. Geol., , 45, 2003 243251.

[17]. V.K.Saxena, andS. Ahmad, Inferring the chemical parameter for the dissolution of fluoride in groundwater. Environ. Geol., 25, 2002, 475-481.

[18]. UNICEF, State of the art report on the extent of fluoride in drinking water and the resulting endemicity in India. Fluorosis Research and Rural Development Foundation for UNICEF, New Delhi, 1999.

[19]. WHO, Fluoride in drinking water, World Health Organization, Geneva, 2006.[20] K.S.Pillai,.andV.A. Stanley, Implication of fluoride - an endless uncertainty. J. Environ. Biol., 2002, 23, 81-87.

[20]. S. Manikandan, S. Chidambaram, AL. Ramanathan, "A study on the high fluoride concentration in the magnesium-rich waters of hard rock aquifer in Krishnagiridistrict, Tamilnadu, India” December-2 2012 253- Springer.com.

[21]. V.Emmanoel., Silva - Filho, Rento, G. SobralBareellos, Christophe Emblanch, Bernard Blavouv, Silva Marie Sella Roland Simler, Julio Vesar Wasserman., 2009.

[22]. S. Aravindan., Sankararan, S., Mahesh kumar, K., Manivel, M., Chandrasekar, Geochemical modeling of groundwater by principle components analysis in hard rock area of Gadilam river basin, TN. Indian Journal of Geochemistry 18, 2004.19 - 31.

[23]. American Public Health Association:Standard methods for the examination of water and wastewater, 20th edition, APHA,Institute, 1998.

[24]. IS 10500 - 1991, Bureau of Indian Standards, India

[25]. R.A.Heikka, Multivariate Monitoring of Water Quality: A Case Study of Lake Simple, Finland. J. Chmonet, 22,2005 747-751.

[26]. P. Palma, ,P. Albarenga, ,V.L. Palma, R.M. Fernandes, A.M.V.M. Soares, I.R. Barbosa, Assessment of Anthropogenic Sources of Water Pollution Using Multivariate Statistical Techniques. A Case Study of Alqueva's Reservoir, Portugal,Environ. Monit. Assess $165,2010539-552$

[27]. B. Helena ,B. Pardo, M. Vega, E. BarradoJ.M. Fernandez, L. Fernandez, Temporal Evolution of Groundwater Composition in an Alluvial Aquifer (PisuergaRiver, Spain) by Principal Component Analysis. Water Res. 34, 2000 807-816.

[28]. L.Tebens, A. Veldkamp , S.B. Kroonenberg The impact of climatechange on the bulk and clay geochemistry of fluvial residual channelinfillings: the Late Weichselian and Early Holocene River Meusesediments (The Netherlands). J. Quaternary Sci., 13 2001 345-356

[29]. S.M.Yidanaa D., Ophoria B., Banoeng-Yakubob. A multivariatestatistical analysis of surface water chemistry data-The Ankobra Basin, Ghana. J. Environ. Manage., 882008 697-707.

[30]. J.HWard JH Hierarchical grouping to optimize an objective function J. Am. Stat. Assoc., 69 1963 $236-244$.

[31]. C.W.Liu,KH.Lin,YM .KuoYM Application of factor analysis in theassessment of groundwater quality in a blackfoot disease area inTaiwan. Sci. Total Environ., 3132003 77-89.

[32]. D.Love,D.Hallbauer,A..Amos,R.Hranova Factor analysis as atool in groundwater quality management: two Southern African casestudies. Phys. Chem. Earth., 29(15-18) 2004.1135-1143.

[33]. .x.ZengC.D.Rasmussen Multivariate statistical characterization of water quality in Lake Lanier, Georgia, USA. J. Environ. Qual. 34 2005:1980-1991 